\begin{tabular}{c} 
ADVANCE RESEARCH JOURNAL OF SOCIAL SCIENCE \\
$\begin{array}{c}\text { ReSEARCH } \\
\text { Volume 11 | Issue 2 | December, 2020 | 61-63 }\end{array}$ \\
$\begin{array}{c}\text { ISSN-0976-5611 } \\
\text { DOI: 10.15740/HAS/ARJSS/11.2/61-63 }\end{array}$ \\
\hline
\end{tabular}

\title{
Status of internet usage among adolescents: A study of locale differences
}

Manpreet Kaur* and Tejpreet Kaur Kang

Department of Human Development and Family Studies, Punjab Agricultural University, Ludhiana (Punjab) India

(Email : manpreetjkbro@gmail.com)

\section{ARTICLE INFO :}

$\begin{array}{lll}\text { Received } & : & 08.07 .2020 \\ \text { Revised } & : & 25.08 .2020 \\ \text { Accepted } & : & 26.09 .2020\end{array}$

KEY WORDS :

Values, Internet usage

HOW TO CITE THIS ARTICLE :

Kaur, Manpreet and Kang, Tejpreet Kaur (2020). Status of internet usage among adolescents: A study of locale differences. Adv. Res. J. Soc. Sci., 11 (2): 61-63, DOI: 10.15740/HAS/ARJSS/11.2/6163.Copyright@2020:HindAgriHorticultural Society

*Author for correspondence

\begin{abstract}
The present study entitled 'Status of internet usage among rural and urban adolescents was undertaken in the Ludhiana and Kapurthala districts of Punjab state. The study was designed to assess the usage of internet among rural and urban adolescents. The sample for the present study comprised of 480 adolescents within the age group of 16 18 years equally distributed over gender and locale (boys $(n=120)$ and girls $(n=120)$ from rural $(n=120)$ as well as urban area $(n=120)$. Internet Usage Scale by Saini and Kaur (2017) was used to assess the patterns/trends of internet usage among adolescents. This scale assessed the internet usage by the adolescents with the help of 20 items. Results revealed that more number of rural respondents were at high level of internet usage as compared to urban respondents. Overall more number of urban respondents used internet than rural respondents.
\end{abstract}

